\title{
KEBIJAKAN APLIKATIF PENJATUHAN PIDANA DENDA PASCA KELUARNYA PERMA NO. 2 TAHUN
}

\author{
Muhammad Iftar Aryaputra, Ani Triwati, Subaidah Ratna Juita \\ Fakultas Hukum Universitas Semarang
}

\begin{abstract}
Abstrak
Ada beberapa permasalahan dari perumusan pidana denda dalam KUHP. Permasalahan tersebut dapat diidentifikasi sebagai berikut, pertama, jumlah pidana denda dalam KUHP belum menyesuaikan dengan keadaan perekonomian saat ini; kedua, perubahan terakhir nominal pidana denda dalam KUHP adalah tahun 1960 melalui UU (Prp) No. 18 Tahun 1960; ketiga, pidana denda dalam KUHP telah usang apabila dibanding dengan ancaman pidana denda dalam undang-undang pidana khusus. Mahkamah Agung sebagai otoritas tertinggi lembaga peradilan di Indonesia, mengeluarkan Peraturan No. 2 Tahun 2012. Melalui Peraturan MA tersebut, pidana denda dan beberapa ketentuan yang berkaitan dengan batasan tindak pidana ringan disesuaikan dengan kondisi perekonomian saat ini. Permasalahan yang dikaji dalam penelitian ini: (1) Bagaimana kebijakan legislatif (formulasi) penanggulangan tindak pidana dengan pidana denda? Bagaimana kebijakan aplikatif penanggulangan tindak pidana dalam KUHP dengan pidana denda sebelum dan sesudah keluarnya Perma No. 2 Tahun 2012? Metode pendekatan yang digunakan dalam penelitian ini adalah yuridis normatif. Selain menggunakan pendekatan normatif, penelitian didukung dengan pendekatan undang-undang dan pendekatan kasus. Data sekunder sebagai data utama dalam penelitian ini terutama berpusat pada perundang-undangan dan putusan pengadilan, yang dianalisis secara kualitatif.
\end{abstract}

Kata Kunci: Denda, Perma, KUHP

Abstract
There are some problems with a formulation of fine in the Penal Code. These problems can be identified as follows, first, the number of fine in the Penal Code do not conform with the current state of the economy; second, the last change of nominal fine in the Penal Code is 1960 through Law (Prp) No. 18 of 1960; Third, the fine in the Penal Code already outdated when compared with the penalty of a fine in the special penal laws. The Supreme Court (MA) as the highest authority of the judiciary in Indonesia, issued Regulation No. 2 Year 2012. Issues examined in this study: (1) How to legislative policy (formulation) the reduction of crime by criminal penalties? How applicable are policies tackling crime in the Criminal Code with a penalty before and after the release of Perma No. 2 of 2012? The method used in this research is normative. In addition to using a normative approach, the research was supported by the approach of legislation and case approach. Secondary data as the primary data in this study primarily focused on legislation and court decisions, which were analyzed qualitatively.

Keywords: Fine, Perma, the Criminal Code

\section{PENDAHULUAN}

Dalam hukum positif di Indonesia, jenis pidana (strafsoort) diatur dalam Pasal $10 \mathrm{KUHP}$, yang membagi pidana menjadi dua bagian yakni pidana pokok dan pidana tambahan. Pidana pokok berdasarkan Pasal 10 KUHP adalah: pidana mati; pidana penjara; pidana kurungan; dan pidana denda. Kemudian dengan dikeluarkannya UU No. 20 Tahun 1946 tentang Hukuman Tutupan pada 31 Oktober 1946, maka ketentuan pidana pokok dalam Pasal 10 KUHP mendapatkan tambahan, yaitu pidana tutupan. Sedangkan pidana tambahan menurut ketentuan Pasal 10 KUHP adalah: (1) pencabutan hak-hak tertentu; (2) perampasan barang-barang tertentu; dan (3) pengumuman putusan hakim.

Pidana pokok yang diformulasikan dalam Pasal 10 KUHP, pada dasarnya harus dijalani terpidana sendiri. Dalam artian, pelaksanaan pidananya tidak boleh diwakili/digantikan oleh orang lain. Hal ini berbeda dengan pidana denda. Menurut Andi Hamzah, pidana denda adalah satusatunya jenis pidana yang dapat dipikul orang lain. ${ }^{1}$ Ditambahkan oleh Andi Hamzah, walaupun pidana denda

1 Andi Hamzah, Sistem Pidana dan Pemidanaan Indonesia, (Jakarta: Pradnya Paramita, 1993), hal 53. 
dijatuhkan secara pribadi kepada terpidana, tetapi tidak ada larangan jika denda tersebut secara sukarela dibayar orang lain atas nama terpidana. ${ }^{2}$

Pidana denda diancamkan untuk kejahatan (mala in se) ataupun pelanggaran (mala prohibita). Dalam prakteknya, pidana denda sangat jarang dijatuhkan, terutama bagi delik-delik yang diatur dalam KUHP. Secara faktual, formulasi pidana denda dalam KUHP dapat dideskripsikan sebagai berikut:

1. jumlah pidana denda dalam KUHP belum menyesuaikan dengan keadaan perekonomian saat ini;

2. perubahan terakhir nominal pidana denda dalam KUHP adalah tahun 1960 melalui UU No. 18/Prp/Tahun 1960;

3. pidana denda dalam KUHP telah usang apabila dibanding dengan ancaman pidana denda dalam undang-undang pidana khusus.

Berdasarkan kondisi faktual di atas, asumsi awal yang dapat diberikan adalah hakim jarang menjatuhkan pidana denda terhadap delik yang diatur dalam KUHP. Untuk mengatasi keadaan tersebut, Mahkamah Agung, pada Tahun 2012 mengeluarkan sebuah Peraturan Mahkamah Agung No. 2 Tahun 2012 tentang Penyesuaian Batasan Tindak Pidana Ringan dan Jumlah Denda dalam KUHP (selanjutnya ditulis Perma No. 2 Tahun 2012 atau Perma).

Semangat yang dihadirkan Mahkamah Agung melalui Perma tersebut patut diapresiasi. Namun yang menjadi pertanyaan, bagaimanakah efektifitas Perma tersebut saat ini. Melihat dari tahun dibuatnya, maka Perma sudah berusia empat tahun. Usia yang cukup untuk dapat memantau seberapa jauh efektifitas penjatuhan denda di KUHP.

Berdasarkan bentangan uraian di atas, cukup beralasan apabila dilakukan kajian akademis mengenai efektifitas

${ }^{2}$ Ibid. pidana denda pasca lahirnya Perma No. 2 Tahun 2012. Hal ini akan dikaji melalui penelitian yang berjudul "Kebijakan Aplikatif Penjatuhan Pidana Denda Pasca Keluarnya Perma No. 2 Tahun 2012".

1. Bagaimana kebijakan formulasi tindak pidana dalam KUHP yang diancam dengan dengan pidana denda?

2. Bagaimana kebijakan aplikatif penanggulangan tindak pidana dalam KUHP dengan pidana denda sebelum dan sesudah keluarnya Perma No. 2 Tahun 2012?

\section{Tujuan Penelitian}

1. Menganalisis kebijakan formulasi tindak pidana dalam KUHP yang diancam dengan dengan pidana denda;

2. Menganilisis kebijakan aplikatif penanggulangan tindak pidana dalam KUHP dengan pidana denda pasca keluarnya Perma No. 2 Tahun 2012.

\section{TINJAUAN PUSTAKA}

\section{Tinjauan Umum tentang Pidana dan Pemidanaan}

Hukum pidana memiliki fungsi hukum pada umumnya, yaitu untuk mengatur hidup kemasyarakatan atau menyelenggarakan tata dalam masyarakat. Sedangkan fungsi khusus hukum pidana menurut Sudarto adalah sebagai pelindung kepentingan hukum terhadap perbuatan yang hendak memperkosanya (rechtsguterschutz) dengan sanksi berupa pidana yang sifatnya lebih tajam. ${ }^{3}$

Karena karakteristiknya yang memiliki sanksi berupa pidana yang sifatnya tajam, maka hukum pidana dijadikan sebagai sarana terakhir dalam menangani perkara pidana. Hukum pidana sengaja mengenakan penderitaan dalam mempertahankan norma-norma yang diakui dalam hukum, sehingga pengenaan hukum

3 Sudarto, Hukum Pidana, (Semarang: Yayasan Sudarto, 1990), hal 11-12.

Jurnal Dinamika Sosial Budaya, Volume 19, Nomor 1, Juni 2017 
pidana seharusnya dijadikan sebagai upaya terakhir apabila sanksi atau upaya-upaya pada cabang hukum lainnya tidak mempan atau dianggap tidak mempan. ${ }^{4}$

Tujuan dari penjatuhan pidana pada umumnya dihubungkan dengan 2 (dua) pandangan besar, yaitu pandangan retributif dan utilitarian. Baik pandangan retributif maupun utilitarian tidak dirumuskan dalam peraturan perundang-undangan. Keduanya hanya ada dan berkembang dalam teori hukum pidana. Teori-teori inilah yang menjadi dasar pembenaran bagi negara dalam menjatuhkan pidana kepada seseorang. ${ }^{5}$

Selanjutnya mengenai teori retributif dan utilitarian akan diurai sebagai berikut:

a. Retributif /teori mutlak/teori pembalasan (vergeldingstheorieen)

Dalam retributif, pidana dijatuhkan semata-mata karena seseorang telah melakukan suatu kejahatan atau tindak pidana. Pidana merupakan akibat mutlak yang harus ada sebagai suatu pembalasan kepada orang yang telah berbuat jahat. ${ }^{6}$ Menurut van Bemmelen tujuan dari teori ini tidak lain dan tidak bukan adalah pidana itu sendiri. $^{7}$

Penjatuhan pidana sematamata dilakukan karena unsur pembalasan terhadap kejahatan yang dilakukan. Dalam teori ini tidak mempertimbangkan sisi kemanusiaan dan mengesampingkan moral

${ }^{4}$ Ibid., hal 13.

5 Chairul Huda, Dari Tiada Pidana Tanpa Kesalahan Menuju Kepada Tiada Pertanggungjawaban Pidana Tanpa Kesalahan: Tinjauan Kritis terhadap Teori Pemisahan Tindak Pidana dan Pertanggungjawaban Pidana, (Jakarta: Kencana Prenada Media Group. 2006), hal 128.

${ }^{6}$ Herbert L. Packer, The Limits of the Criminal Sanction, (California: Stanford University Press, 1968), hal 9.

7 J. M. van Bemmelen, Hukum Pidana 1 - Hukum Pidana Material Bagian Umum, terjemahan Hasnan, (Bandung: Binacipta, 1987), hal 25. dari hukum pidana, sehingga tujuan penjatuhan pidana justru tidak akan tercapai. ${ }^{8}$

b. Utilitarian/teori tujuan/teori relatif (doeltheorien)

Teori ini lahir sebagai kritik atas teori retributif yang dirasa tidak sesuai dengan sisi kemanusiaan dan moral hukum pidana. Adanya pembalasan sebagai suatu tujuan pemidanaan dapat menghasilkan suatu keadilan yang brutal. Sebagaimana diungkapkan Bacon, seorang filosof Inggris, "revenge is a kind of wild justice". 9

Dalam teori ini, Muladi menyatakan bahwa pemidanaan bukan sebagai pembalasan atau pengimbalan kepada orang yang telah melakukan suatu tindak pidana, tetapi mempunyai tujuantujuan tertentu yang bermanfaat, oleh karena itu teori ini juga disebut dengan teori utilitarian. ${ }^{10}$ Sanksi pidana ditekankan pada tujuannya, yakni untuk mencegah agar orang tidak melakukan kejahatan, maka bukan bertujuan untuk pemuasan absolut atas keadilan. ${ }^{11}$

Packer menyatakan, "The utilitarian rejects retributition as a basis for punishment on the ground that suffering is always an evil and that there is no justification for making people suffer...". ${ }^{12}$

${ }^{8}$ Yesmil Anwar. dan Adang, Pembaruan Hukum Pidana Reformasi Hukum Pidana, (Jakarta: PT Gramedia Widiasarana Indonesia, 2008), hal 134

${ }^{9}$ Bacon sebagaimana dikutip Neil Mac Cormick and David Garland, Sovereign States and Vengeful Victims: The Problem of the Right to Punish. Makalah dalam Andrew Asworth dan Martin Wasik (ed), Fundamentals of Sentencing Theory-Essays in Honour of Andrew von Hirsch, (Oxford: Clarendon Press, 1998), hal 11.

10 Muladi dan Barda Nawawi Arief, Teori-Teori dan Kebijakan Pidana, (Bandung: Alumni, 2005), hal 16.

11 Vos sebagaimana dikutip Abidin, Z.

Dkk., Pemidanaan, Pidana, dan Tindakan dalam Rancangan KUHP, (Position Papper Advokasi oleh ELSAM-Lembaga Studi dan Advokasi Masyarakat, 2005), hal 11.

${ }^{12}$ Herbert L. Packer, Op. Cit., hal 11. 
Pandangan utilitarian menolak pembalasan sebagai dasar untuk menjatuhkan hukuman, hal ini dikarenakan penderitaan merupakan suatu bentuk kejahatan, dan tidak ada pembenaran untuk membuat seseorang menderita.

c. Teori Gabungan (verenigingstheorien)

Teori gabungan ini pertama kali diajukan oleh Pellegrino Rossi (17871848), di mana dalam teori ini mengkombinasi teori retributif dan teori utilitarian yang bertujuan selain sebagai pembalasan (retributif) atas kesalahan penjahat, juga dimaksudkan untuk melindungi masyarakat guna mewujudkan ketertiban (utilitarian). ${ }^{13}$ Selanjutnya Rossi menyatakan bahwa salah satu tujuan pidana adalah perbaikan tata tertib masyarakat. Jadi dalam hal ini, pidana harus memberikan manfaat kepada tata tertib masyarakat. ${ }^{14}$

Senada dengan Rossi,

Bemmelen menyatakan bahwa dalam teori gabungan bertujuan untuk membalas kesalahan dan mengamankan masyarakat, sedangkan tindakan bermaksud untuk mengamankan dan memelihara tujuan, sehingga pidana dan tindakan dimaksudkan mempersiapkan untuk mengembalikan terpidana kedalam masyarakat. ${ }^{15}$ Dari rumusan Bemmelen tersebut, maka terlihat bahwa Bemmelen juga menganut model double track system. ${ }^{16}$

\section{Tinjauan Umum tentang Pidana Denda}

Menurut Jan Remmelink, penjatuhan pidana denda terhadap terpidana memiliki beberapa keuntungan: pertama,

13 Lihat Muladi dan Barda Nawawi Arief, Op. Cit., hal 19; van Bemmelen, Op. Cit., hal 29; Yesmil Anwar dan Adang, Op. Cit., hal 137.

14 Pellegrino Rossi sebagaimana dikutip van Bemmelen, Op. Cit., hal 29.

15 Andi Hamzah menyebut bahwa van Bemmelen merupakan penganut teori gabungan. Lihat dalam Andi Hamzah, Asas Hukum Pidana, (Jakarta: Rineka Cipta, 1994), hal 36. 7. pidana denda tidak menyebabkan stigmatisasi. Kedua, pelaku yang dikenakan pidana denda dapat tetap tinggal bersama keluarga dan lingkungan sosialnya. Ketiga, pidana denda tidak menyebabkan pelaku kehilangan pekerjaannya. Keempat, pidana denda dengan mudah dapat dieksekusi. Kelima, negara tidak menderita kerugian akibat penjatuhan pidana denda. ${ }^{17}$

Menurut Aruan Sakidjo dan Bambang Poernomo, pidana denda dapat diartikan sebagai suatu kewajiban membayar sejumlah uang, sebagaimana telah ditentukan di dalam putusan hakim yang dibebankan kepada terpidana atas pelanggaran atau kejahatan yang telah dilakukannya. $^{18}$ Sebagai pidana pokok, pidana denda diancamkan terhadap hampir keseluruhan pelanggaran (overtredingen) yang diatur dalam buku III KUHP, dan sebagian kejahatan yang diatur dalam buku II KUHP.

Menurut Pasal 30 ayat (1) KUHP, besaran pidana denda yang dijatuhkan kepada terpidana paling sedikit dua puluh lima sen. Ketentuan ini kemudian diubah dengan UU (Prp) No. 18 Tahun 1960, sehingga minimal denda yang dijatuhkan harus dibaca sebesar 3 rupiah 75 sen.

Pidana denda yang tidak dibayar oleh terpidana, maka pidana denda dapat diganti dengan pidana kurungan. Lamanya pidana kurungan pengganti denda dinyatakan dalam Pasal 30 ayat (3), selama minimal satu hari dan paling lama enam bulan. Dalam hal terjadi pemberatan karena ada perbarengan tinda pidana (concursus) dan pengulangan tindak pidana (recidive) atau karena ketentuan Pasal 52 dan 52a KUHP, pidana kurungan pengganti dapat

17 Jan Remmelink sebagaimana dikutip Eddy O.S. Hiariej, Prinsip-Prinsip Hukum Pidana, (Yogjakarta: Cahaya Atma Pustaka, 2014), hal 401.

18 Aruan Sakidjo dan Bambang Poernomo, Hukum Pidana Dasar Aturan Umum Hukum Pidana Terkodifikasi, (Jakarta: Ghalia Indonesia, 1990), hal 95. 
dijadikan maksimal 8 bulan, tetapi dengan ketentuan tidak boleh sekali-kali lamanya pidana kurungan pengganti denda melebihi 8 (delapan) bulan kurungan.

Menurut ketentuan Pasal 31 KUHP, terpidana dapat menjalani kurungan pengganti denda tanpa menunggu batas waktu pembayaran denda. Terpidana dapat membebaskan dirinya dari pidana kurungan pengganti dalam hal yang bersangkutan telah membayar dendanya. Pembayaran sebagian denda, baik sebelum maupun sesudah mulai menjalani pidana kurungan pengganti, membebaskan terpidana dari sebagian pidana kurungan yang diseimbangkan dengan bagian yang dibayarkannya.

\section{Kebijakan Kriminal Penanggulangan Tindak Pidana}

Penggunaan hukum pidana sebagai salah satu sarana dalam mengatasi masalah sosial (temasuk kejahatan dan pelanggaran), merupakan bagian dari suatu kebijakan penegakan hukum (criminal law policy) atau yang lebih familiar dengan istilah kebijakan kriminal (criminal policy). ${ }^{19}$ Dalam ruang lingkup yang lebih luas, kebijakan penegakan hukum merupakan bagian dari kebijakan sosial (social defence). Kebijakan sosial di sini dapat diartikan sebagai suatu usaha rasional dari masyarakat untuk mencapai kesejahteraan masyarakat. $^{20}$ Dengan demikian, dapat disimpulkan bahwa, kebijakan penegakan hukum/kebijakan kriminal (criminal policy) merupakan suatu kebijakan yang turut mendukung langkah dalam menciptakan kesejahteraan bagi masyarakat. Dengan kata lain, kebijakan kriminal adalah suatu kebijakan yang memiliki arah dan tujuan demi terwujudnya nilai-nilai kesejahteraan masyarakat.

19 Barda Nawawi Arief, Kebijakan Legislatif dalam Penanggulangan Kejahatan dengan Pidana Penjara,(Yogjakarta: Genta Publishing, 2010), hal 17.

20 Ibid.
Pengertian kebijakan kriminal sudah dikemukakan oleh beberapa pakar, misalnya oleh Marc Ancel yang mendefiniskan kebijakan kriminal sebagai usaha rasional dari masyarakat dalam menangani kejahatan (criminal policy is the rational organization of the social reactions to crime) ${ }^{21}$ Kemudian dari pendapat Marc Ancel tersebut, Peter Hoefnagels memberikan suatu definisi tersendiri bahwa criminal policy merupakan suatu ilmu tentang kebijakan yang menjadi bagian dari suatu kebijakan yang lebih besar yaitu kebijakan penegakan hukum (criminal policy is as a science of policy is part of a large policy: the law enforcement). ${ }^{22}$ Masih menurut Hoefnagels, criminal policy diwujudkan sebagai ilmu dan untuk diterapkan..$^{23}$

Sebagaimana telah disinggung di atas, kebijakan kriminal merupakan bagian integral dari kebijakan sosial. Di dalamnya terkandung usaha untuk perlindungan masyarakat (social defence) dan usaha kesejahteraan masyarakat (social welfare) ${ }^{24}$ Dalam kajian yang lebih khusus, kebijakan kriminal meliputi pula kebijakan hukum pidana (penal policy) dan kebijakan non hukum pidana (non penal policy). ${ }^{25}$

\section{Kebijakan Hukum Pidana (Penal Policy)}

Kebijakan hukum pidana (penal policy) dan kebijakan non hukum pidana (non penal policy) merupakan bagian dari kebijakan kriminal, sebagai suatu upaya yang dilakukan guna menanggulangi tindak pidana yang terjadi masyarakat. Kebijakan hukum pidana (penal policy) dapat disebut

21 Marc Ancel sebagaimana dikutip G. Peter Hoefnagels, The Other Side of Criminology-An Inversion of the Concept of Crime, (Holland: Kluwer-Deventer, 1969), hal 57.

${ }^{22}$ Ibid.

${ }^{23}$ Ibid.

${ }^{24}$ Barda Nawawi Arief, Bunga Rampai Kebijakan Hukum Pidana Perkembangan Penyusunan Konsep KUHP Baru, (Jakarta: Kencana Prenada Media Group, 2011), hal 4.

${ }^{25}$ Ibid., hal 5. 
juga dengan politik hukum pidana. Dalam istilah asing, politik hukum pidana disebut juga dengan penal policy, criminal law policy, atau strafrechtspolitiek. ${ }^{26}$ Politik hukum pidana sangat terkait erat dengan upaya pembaruan hukum pidana, terutama terhadap hukum pidana materiil yang masih merupakan warisan Belanda.

Di dalam penal policy, menurut Sudarto, terkandung makna sebagai suatu usaha untuk mewujudkan peraturan perundang-undangan pidana yang sesuai dengan keadaan dan situasi pada suatu waktu dan untuk masa yang akan datang. ${ }^{27}$ Dari pendapat Sudarto ini, terlihat bahwa parameter dalam menentukan perundangundangan pidana yang ideal bukan hanya yang dapat diberlakukan pada masa kini, namun juga untuk masa yang akan datang.

Fungsionalisasi politik hukum pidana/kebijakan hukum pidana menurut Barda Nawawi Arief yang mengutip pendapat Bassiouni, dapat dilakukan melalui tiga tahap, yaitu tahap formulasi, aplikasi, dan eksekusi. ${ }^{28}$ Masih menurut Barda Nawawi, dalam kebijakan hukum pidana, tahap formulasi merupakan tahap paling strategis. Apabila terdapat kelemahan dalam tahap formulasi, maka akan berdampak pada terhambatnya upaya pencegahan dan penanggulangan kejahatan dalam tahap aplikasi dan eksekusi. ${ }^{29}$

Tahap formulasi mengandung makna sebagai suatu usaha untuk merumuskan peraturan yang dilakukan oleh lembaga eksekutif bersama legislatif yang

${ }^{26}$ Barda Nawawi Arief, Bunga Rampai Kebijakan Hukum Pidana... Ibid., hal 26.

27 Sudarto, Hukum Pidana dan Perkembangan Masyarakat - Kajian Terhadap Pembaruan Hukum Pidana, (Bandung: Sinar Baru, 1983), hal 93

28 Bassiouni sebagaimna dikutip Barda Nawawi Arief, Masalah Penegakan Hukum dan Kebijakan Hukum Pidana Dalam Penanggulangan Kejahatan, (Jakarta: Kencana, 2008), hal 79.

29 Barda Nawawi Arief, Masalah Penegakan Hukum..., Ibid. dituangkan dalam suatu undang-undang maupun yang masih berupa rancangan undang-undang. Tahap aplikasi dapat dimaknai dengan penerapan kebijakan legislatif/formulatif yang dilakukan oleh aparat penagak hukum. Sedangkan tahap eksekusi dapat dimaknai sebagai tahapan pelaksanaan eksekusi pidana oleh lembaga eksekutor.

\section{METODE PENELITIAN}

Pendekatan yang digunakan dalam penelitian ini adalah normatif, atau yang lebih familiar dengan istilah penelitian yuridis normatif. ${ }^{30}$ Menurut Soerjono Soekanto, penelitian hukum normatif merupakan penelitian terhadap bahan pustaka atau data sekunder, yang mencakup bahan hukum primer, sekunder, dan tersier. ${ }^{31}$ Pendekatan normatif yang digunakan terutama didapatkan melalui pendekatan perundang-undangan (statute approach) dan pendekatan kasus (case approach).

Penelitian ini merupakan penelitian deskriptif analitis. Deskriptif analitis dimaksudkan untuk melakukan analisis/pengkajian terhadap gambaran atau pemaparan mengenai subyek dan obyek penelitian dan melukiskan tahap formulasi dan tahap aplikasi dalam kebijakan hukum pidana di Indonesia yang terkait dengan pidana denda.

Karena pendekatan yang digunakan dalam penelitan ini adalah pendekatan normatif, sehingga data utama yang digunakan adalah data sekunder. Menurut Ronny Hanitijo Soemitro, data sekunder dalam bidang hukum dapat dibedakan

30 Barda Nawawi Arief, Penelitian Hukum Normatif (Suatu Upaya Reorientasi Pemahaman), dipaparkan dalam Penataran Metodologi Penelitian Hukum, Universitas Jendral Soedirman, Purwokerto, 11-15 September 1995, hal 5-6.

31 Soerjono Soekanto, Pengantar Penelitian Hukum, (Jakarta: UI Perss, 2006), hal 52.

Jurnal Dinamika Sosial Budaya, Volume 19, Nomor 1, Juni 2017 
menjadi bahan hukum primer, bahan hukum sekunder, bahan hukum tersier. ${ }^{32}$

Bahan hukum primer merupakan bahan hukum yang memiliki kekuatan mengikat, sehingga dalam penelitian ini, bahan hukum primer berpusat pada peraturan perundang-undangan yang berlaku di Indonesia. Adapun bahan hukum primer yang peneliti gunakan adalah KUHP dan Peraturan Mahakamah Agung (Perma) No 2 Tahun 2012 tentang tentang Penyesuaian Batasan Tindak Pidana Ringan dan Jumlah Denda dalam KUHP. Bahan hukum sekunder yang digunakan dalam penelitian ini adalah Rancangan Kitab Undang-Undang Hukum Pidana (RKUHP), hasil-hasil penelitian yang telah dilakukan oleh para sarjana hukum, tulisan-tulisan ilmiah hasil karya ahli hukum serta pendapat ahli hukum. Bahan hukum tersier yang digunakan dalam penelitian ini adalah kamus hukum maupun kamus bahasa Indonesia.

Pengumpulan data dalam penelitian ini dilakukan dengan cara studi kepustakaan. Studi kepustakaan dilakukan dengan cara penelusuran langsung melalui peraturan perundang-undangan, buku, jurnal, serta bahan-bahan internet. Dalam studi kepustakaan akan menghasilkan data sekunder sebagai data utama dalam penelitian ini.

Soerjono Soekanto mengemukakan, analisis dapat dirumuskan sebagai suatu proses penguraian secara sistematis dan konsisten terhadap gejala-gejala tertentu. ${ }^{33}$ Terdapat keterkaitan yang erat antara metode analisis data dengan pendekatan masalah yang digunakan. Data yang telah

${ }^{32}$ Ronny Hanitijo Soemitro, Metodologi Penelitian Hukum dan Jurimetri, (Jakarta: Ghalia Indonesia, 1994)., hal 11.

33 Soerjono Soekanto sebagaimana dikutip Barda Nawawi Arief, Kebijakan Legislatif Dalam Penanggulangan Kejahatan dengan Pidana Penjara, (Yogyakarta: Genta Publisihing, 2010), hal 68. diperoleh selanjutnya dianalisis secara kualitatif.

\section{PEMBAHASAN}

\section{Kebijakan Formulasi Tindak Pidana dalam KUHP yang diancam Pidana Denda}

Pidana denda sebagai salah satu jenis pidana denda memiliki keunikan tersendiri, yaitu: ${ }^{34}$

1. Semua negara memiliki denda sebagai sanksi pidana.

2. Pidana denda merupakan pidana tertua, setua pidana mati.

3. Pidana denda tidak menyebabkan stigmatisasi.

4. Pelaku yang dikenakan pidana denda dapat tetap tinggal bersama keluarga dan lingkungan sosialnya.

5. Pidana denda tidak menyebabkan pelaku kehilangan pekerjaannya.

6. Pidana denda dengan mudah dapat dieksekusi.

7. Negara tidak menderita kerugian akibat penjatuhan pidana denda. ${ }^{35}$

Pidana denda dapat diartikan sebagai suatu kewajiban membayar sejumlah uang, sebagaimana telah ditentukan di dalam putusan hakim yang dibebankan kepada

${ }^{34}$ Poin pertama berdasarkan pengamatan penulis pribadi yang didasarkan pada pendekatan komparatif, dengan beberapa sampel misal Albania (Pasal 29 KUHP Albania); Armenia (Pasal 49 KUHP Armenia), Bulgaria (Pasal 37 KUHP Bulgaria); China (Pasal 29 KUHP China); Inggris (Criminal Law Act 1967 UK); Ethiopia (Pasal 88 KUHP Ethiopia), dan negara-negara lain yang tidak mungkin dituliskan satu persatu.

Poin 2 dikutip dari Andi Zainal Farid dan Andi Hamzah, Bentuk-Bentuk Khusus Perwujudan Delik (Percobaan, Penyertaan, dan Gabungan Delik) dan Hukum Penitensier, (Jakarta: Rajagrafindo, 2006), hal 294.

Poin 3-7 dikutip dari Jan Remmelink sebagaimana dikutip Eddy O.S. Hiariej, lihat hal 11 .

35 Jan Remmelink sebagaimana dikutip Eddy O.S. Hiariej, Prinsip-Prinsip Hukum Pidana, (Yogjakarta: Cahaya Atma Pustaka, 2014), hal 401.

Jurnal Dinamika Sosial Budaya, Volume 19, Nomor 1, Juni 2017 
terpidana atas pelanggaran atau kejahatan yang telah dilakukannya. ${ }^{36}$

Sebagai pidana pokok, pidana denda diancamkan terhadap hampir keseluruhan pelanggaran (overtredingen) yang diatur dalam buku III KUHP, dan sebagian kejahatan yang diatur dalam buku II KUHP. Dilihat dari sudut strafmaat, berdasar Pasal 30 ayat (1) KUHP, besaran pidana denda yang dijatuhkan kepada terpidana paling sedikit dua puluh lima sen. Ketentuan ini kemudian diubah dengan UU (Prp) No. 18 Tahun 1960, sehingga minimal denda yang dijatuhkan harus dibaca sebesar 3 rupiah 75 sen. Sedangkan pidana denda terbanyak terdapat dalam Pasal 251 dan 403 KUHP, yaitu Rp. 10.000,00. Setelah keluarnya UU No.18/Prp/Tahun 1960, semua denda dalam KUHP menjadi 15 kali lipat.

Di KUHP, pidana denda dijatuhkan terhadap kejahatan dan pelanggaran. Khusus untuk kejahatan, tidak semua kejahatan yang diatur dalam Buku II KUHP diancam dengan pidana denda. Untuk tindak pidana berupa kejahatan, pidana denda diancamkan terhadap 119 pasal di Buku II KUHP, yaitu Pasal 114, 117, 118, 124, 137, 142, 142a, 143, 144, 149, 154, 154a, 155, 156, 157, 158, 159, 160, 161, $162,163,164,165,166,167,168,169$, 174, 176, 177, 178, 180, 181, 183, 188, 191 bis, 191 ter, 193, 195, 197, 199, 201, 203, 205, 207, 208, 209, 212, 216, 217, 218, 219, 221, 222, 227, 228, 229, 231, 232, 238, 239,241, 249, 250, 251, 260, 261, 275, 281, 282, 283, 296, 299, 300, 302, 303, 303 bis, 304, 310, 315, 320, 321, 322, 323, 334, $335,351,352,360,362,364,372,373$, 379, 380, 382 bis, 384, 393, 403, 406, 407, 409, 418, 426, 427, 429, 458, 464, 469, 470, 473, 474, 475, 476, 477, 480, 482, 483, dan 484 KUHP. Dengan demikian,

36 Aruan Sakidjo dan Bambang Poernomo, Hukum Pidana Dasar Aturan Umum Hukum Pidana Terkodifikasi, (Jakarta: Ghalia Indonesia, 1990), hal 95. sebanyak $32 \%$ kejahatan dalam Buku II KUHP memiliki ancaman sanksi pidana denda. Sanksi pidana denda dalam Buku II KUHP dirumuskan secara alternatif.

Sedangkan untuk pelanggaran, pada umumnya pidana denda dijadikan sebagai ancaman baik dirumuskan secara tunggal (contoh Pasal 495 KUHP), alternatif (contoh Pasal 493 KUHP). Dalam Buku III, ada 4 pasal yang tidak mencantumkan sanksi pidana, yaitu Pasal 504, 505, 506, dan 520 KUHP. Ini berarti, sebesar $97 \%$ tindak pidana pelanggaran diancam dengan sanksi pidana denda.

Permasalahan yang muncul dari pidana denda dalam KUHP adalah jumlahnya yang tidak menyesuaikan dengan perkembangan tingkat perekonomian bangsa Indonesia. Nominal tersebut pernah dilakukan penyesuaian melalui Perppu No. 18 Tahun 1960 tentang Perubahan Jumlah Hukuman Denda dalam KUHP dan Ketentuan-Ketentuan Pidana Lainnya yang dikeluarkan Sebelum Tanggal 17 Agustus 1945. Dalam perkembangannya, Perppu No. 18 Tahun 1960 ditetapkan menjadi UU melalui UU No. 1 Tahun 1961.

Menurut ketentuan Pasal 1 ayat (1) Perppu No. 18 Tahun 1960, ditegaskan bahwa:

Tiap jumlah hukuman denda yang diancamkan, baik dalam Kitab Undangundang Hukum Pidana, sebagaimana beberapa kali telah ditambah dan diubah dan terakhir dengan Undang-Undang No. 1 tahun 1960, maupun dalam ketentuanketentuan pidana lainnya yang dikeluarkan sebelum tanggal 17 Agustus 1945, sebagaimana telah diubah sebelum hari mulai berlakunya Peraturan Pemerintah Pengganti Undang-undang ini, harus dibaca dalam mata uang rupiah dan dilipatgandakan menjadi lima belas kali.

Dengan demikian, setiap denda dalam KUHP dilipatgandakan menjadi lima belas kali. Berdasarkan ketentuan tersebut, maka 
sanksi pidana denda terberat adalah $\mathrm{Rp}$. 150.000,00 (seratus lima puluh ribu rupiah) sebagaimana terdapat dalam Pasal 251 dan 403 KUHP. Ketentuan Perppu No. 18 tersebut tidak berlaku terhadap Pasal 303 ayat (1) dan 303 bis. Berdasarkan UU No. 7 Tahun 1974 tentang Penertiban Perjudian, denda dalam Pasal 303 ayat (1) menjadi Rp. 25.000.000,00 sedangkan Pasal 303 bis menjadi Rp. 10.000.000,00.

Nominal pidana denda dalam KUHP yang tidak mengikuti laju perekonomian bangsa, membuat pidana denda tidak efektif. Hakim lebih memilih menjatuhkan pidana penjara daripada denda. Sampai saat ini, pidana penjara masih menjadi primadona. Hal ini dapat kita lihat dari beberapa alasan:

1. Pidana penjara adalah jenis pidana paling banyak yang diancamkan dalam KUHP, baik dalam Buku II atau Buku III, yaitu sebesar 97,96\%. Demikian pula untuk delik di luar KUHP, kurang lebih 96,67 \% diancam pidana penjara. ${ }^{37}$

2. Pidana penjara adalah jenis pidana yang paling sering dijatuhkan oleh hakim. $^{38}$

Kebijakan Aplikatif Penanggulangan Tindak Pidana dalam KUHP dengan Pidana Denda Sebelum dan Sesudah Keluarnya Perma No. 2 Tahun 2012

Berdasaran hasil penelusuran terhadap putusan-putusan pengadilan negeri

37 Lihat dalam Barda Nawawi Arief, Kebijakan Legislatif dalam Penanggulangan Kejahatan dengan Pidana Penjara,(Yogjakarta: Genta Publishing, 2010), hal 71-75. Pernyataan tersebut merupakan hasil dari penelitian disertasi tahun 1986. Walaupun penelitian tersebut dilakukan pada dekade 1980-an, namun hasil penelitian masih ada relevansi dengan masa sekarang.

38 Ibid., hal 98-102. Data tersebut berdasarkan penelitian disertasi yang dilakukan dalam kurun waktu tahun 1973-1982. Dalam kurun waktu tersebut, pidana penjara dijatuhkan oleh hakim pengadilan negeri dengan prosentase $81,84 \%$. Sedangkan prosentase penjatuhan pidana denda hanya sebesar $3,8 \%$. di beberapa pengadilan, sepengamatan peneliti, mayoritas pidana yang dijatuhkan adalah penjara. Putusan pidana penjara lebih dipilih sebagai strasoort dalam menjatuhkan putusan pemidanaan terhadap kejahatan ringan atau kejahatan yang memiliki alternatif sanksi pidana penjara atau denda.

Peneliti mengambil beberapa sampel putusan dari berbagai pengadilan negeri di Indonesia, sebelum keluarnya Perma No. 2 Tahun 2012 (Perma dikeluarkan tanggal 27 Februari 2012). 
Hasil olah sampel peneliti dapat dilihat dalam tabel berikut:

\begin{tabular}{|c|c|c|c|c|c|}
\hline No & $\begin{array}{l}\text { Nomor } \\
\text { Putusan }\end{array}$ & Terdakwa & $\begin{array}{l}\text { Tindak Pidana } \\
\text { yang terbukti }\end{array}$ & $\begin{array}{c}\text { Ancaman Pidana } \\
\text { Pasal ybs }^{39}\end{array}$ & Putusan \\
\hline 1. & $\begin{array}{c}1237 \\
\mathrm{~K} / \mathrm{Pid} / 2004\end{array}$ & $\begin{array}{l}\text { Muhammad Rizal } \\
\text { bin Abdul Hamid }\end{array}$ & $\begin{array}{l}\text { Penganiayaan ringan } \\
\text { (352 KUHP) }\end{array}$ & $\begin{array}{l}\text { Penjara maks } 3 \text { bulan } \\
\text { atau maks denda Rp. } \\
4.500\end{array}$ & $\begin{array}{lll}\begin{array}{l}\text { Pidana } \\
\text { bulan }\end{array} & \text { penjara } & 3 \\
& & \end{array}$ \\
\hline 2. & $\begin{array}{l}158 \text { / Pid.B / } \\
2007 \text { / PN.Bjn }\end{array}$ & $\begin{array}{l}\text { 1. Kasingun bin } \\
\text { San Lamin; } \\
\text { 2. Kardimin bin } \\
\text { Sanari; } \\
\text { 3. Edy alias Jaedi } \\
\text { bin Sanadi; } \\
\text { 4. Hadi Jamil bin } \\
\text { Yasroni. }\end{array}$ & $\begin{array}{l}\text { Perjudian } \\
\text { KUHP Jo. } 55 \text { ayat (1) } \\
\text { ke } 1 \text { KUHP) }\end{array}$ & $\begin{array}{l}\text { Pidana penjara maks } \\
10 \text { tahun atau denda } \\
\text { maks Rp. } 25.000 .000\end{array}$ & \begin{tabular}{ll}
\multicolumn{3}{l}{ Masing-masing } \\
dengan & pidana \\
penjara 4 bulan 15 \\
hari
\end{tabular} \\
\hline 3. & $\begin{array}{l}1041 \text { Pid.B / } \\
2009 \text { / } \\
\text { PN.Bwi. }\end{array}$ & Slamet Santoso & $\begin{array}{l}\text { Perjudian (Pasal } 303 \\
\text { KUHP) }\end{array}$ & $\begin{array}{l}\text { Pidana penjara maks } \\
10 \text { tahun atau denda } \\
\text { maks Rp. } 25.000 .000\end{array}$ & Penjara 8 bulan \\
\hline 4. & $\begin{array}{l}\text { 1050/Pid.B/ } \\
\text { 2009/PN.BWI. }\end{array}$ & $\begin{array}{l}\text { Suri alias } \mathrm{P} . \\
\text { Hendrik }\end{array}$ & $\begin{array}{l}\text { Perjudian (Pasal } 303 \\
\text { KUHP) }\end{array}$ & $\begin{array}{l}\text { Pidana penjara maks } \\
10 \text { tahun atau denda } \\
\text { maks Rp. } 25.000 .000\end{array}$ & $\begin{array}{l}\text { Penjara } 2 \text { bulan } 15 \\
\text { hari }\end{array}$ \\
\hline 5. & $\begin{array}{l}\text { 118/PID.B/ } \\
2009 \\
\text { /PN.BJN. }\end{array}$ & $\begin{array}{l}\text { Rachmad Illahi bin } \\
\text { Musman }\end{array}$ & $\begin{array}{l}\text { Memperjualbelikan } \\
\text { pupuk bersubsidi di } \\
\text { luar peruntukkannya } \\
\text { (Pasal } 6 \text { ayat (1) } \\
\text { huruf a Undang- } \\
\text { Undang Darurat No.7 } \\
\text { Tahun } 1955 \text { tentang } \\
\text { Pengusutan, } \\
\text { Penuntutan dan } \\
\text { Peradilan Tindak } \\
\text { Pidana Ekonomi Jo. } \\
\text { Pasal } 19 \text { ayat (2) Jo } \\
\text { Pasal } 19 \text { ayat } \\
\text { (4) Peraturan Menteri } \\
\text { Perdagangan } \\
\text { No.03/M.Dag/2/2006 } \\
\text { ) }\end{array}$ & $\begin{array}{l}\text { hukuman penjara } \\
\text { selama-lamanya } \\
\text { enam } \\
\text { tahun dan hukuman } \\
\text { denda setinggi- } \\
\text { tingginya lima ratus } \\
\text { ribu rupiah }\end{array}$ & $\begin{array}{l}\text { Pidana } 3 \text { (tiga) bulan } \\
\text { penjara dan pidana } \\
\text { denda sebesar Rp. } \\
50.000,00\end{array}$ \\
\hline 6. & $\begin{array}{c}\text { 155/Pid.B/201 } \\
1 / \\
\text { PN.Dmk }\end{array}$ & $\begin{array}{l}\text { Imam Junaidi bin } \\
\text { Suyitno }\end{array}$ & $\begin{array}{l}\text { Penghinaan (310 ayat } \\
\text { (1) KUHP) }\end{array}$ & $\begin{array}{l}\text { Pidana penjara maks } \\
9 \text { bulan atau maks } \\
\text { denda Rp. } 4.500\end{array}$ & $\begin{array}{llr}\text { pidana } & & \text { penjara } \\
\text { selama } & 4 & \text { (empat) } \\
\text { bulan } & & \\
\end{array}$ \\
\hline 7. & $\begin{array}{c}\text { 241/Pid } \\
. B / 2011 / \text { PN } \\
\text { Dmk } \\
\end{array}$ & $\begin{array}{l}\text { Imam Setiawan bin } \\
\text { Sujak }\end{array}$ & $\begin{array}{l}\text { Perjudian (Pasal } 303 \\
\text { ayat (1) ke }-2 \\
\text { KUHP) }\end{array}$ & $\begin{array}{l}\text { Pidana penjara maks } \\
10 \text { tahun atau denda } \\
\text { maks Rp. } 25.000 .000\end{array}$ & $\begin{array}{l}\text { pidana penjara } \\
\text { selama } 4 \text { (empat) } \\
\text { bulan }\end{array}$ \\
\hline 8. & $\begin{array}{c}\text { 349/Pid.B/201 } \\
\text { 1/ PN.BTA }\end{array}$ & $\begin{array}{l}\text { Sunariadi bin } \mathrm{H} . \\
\text { Muzir }\end{array}$ & $\begin{array}{l}\text { Penggelapan } \quad(372 \\
\text { KUHP) }\end{array}$ & $\begin{array}{l}\text { Pidanan penjara maks } \\
4 \text { tahun atau denda } \\
\text { maks Rp. } 900\end{array}$ & $\begin{array}{l}\text { Pidana penjara } 1 \\
\text { (satu) tahun }\end{array}$ \\
\hline 9. & $\begin{array}{c}\text { 20/Pid } \\
. B / 2011 / \text { PN. } \\
\text { Pwi }\end{array}$ & Mulyadi bin Hosen & $\begin{array}{l}\text { Penadahan } \\
\text { KUHP) }\end{array}$ & $\begin{array}{l}\text { Pidana Penjara maks } \\
4 \text { tahun atau denda } \\
\text { maks Rp. } 900,00\end{array}$ & $\begin{array}{l}\text { Pidana } 5 \text { (lima) bulan } \\
\text { penjara }\end{array}$ \\
\hline
\end{tabular}

${ }^{39}$ Berdasarkan Perppu No. 18 Tahun 1960, semua denda dilipatgandakan menjadi 15 kali.

Jurnal Dinamika Sosial Budaya, Volume 19, Nomor 1, Juni 2017 
Berdasar sampel putusan di atas, tindak pidana yang terbukti dapat dikualifikasikan menjadi dua jenis, yaitu kejahatan ringan dan tindak pidana yang diancam dengan salah satunya adalah pidana denda. Kualifikasi yang pertama meliputi Putusan No. 1237 K/Pid/2004 (poin 1). Sedangkan kualifikasi kedua meliputi putusan poin nomor 2, 3, 4, 6, 7, 8, dan 9. Khusus dalam perkara komor 5 (Putusan 118/PID.B/2009 /PN.BJN.), bukan termasuk delik dalam KUHP, sehingga tidak termasuk dalam obyek kajian penelitian ini. Namun demikian, putusan nomor 118/PID.B/2009 /PN.BJN penting untuk dikaji sebagai bahan komparasi.

Dari tabel di atas, dapat kita simpulkan bahwa sebelum keluarnya Perma No. 2 Tahun 2012, untuk delik-delik dalam KUHP tidak ada satupun hakim yang menjatuhkan pidana denda. Padahal untuk kejahatan ringan, pidana denda menjadi salah satu alternatif jenis pidana yang bisa dijatuhkan oleh hakim. Sedangkan delik penghinaan, penadahan, dan penggelapan juga memiliki ancaman pidana denda yang diancamkan secara alternatif. Dengan demikian, hakim sebenarnya diberikan pilihan untuk memilih jenis pidana yang akan dijatuhkan kepada terdakwa. Dari keseluruhan sampel putusan di atas, terlihat bahwa hakim tidak menggunakan pidana denda. Hakim lebih memilih menjatuhkan pidana penjara, walaupun penjara yang dijatuhkan tergolong pidana penjara pendek.

Jika menilik model perumusan kejahatan dalam Buku II KUHP yang memuat sanksi pidana denda, maka tidak ada satu pasal dalam KUHP yang merumuskan pidana denda secara tunggal. Dengan demikian, pidana denda dalam Buku II KUHP senantiasa dirumuskan secara alternatif. Model perumusan sanksi pidana secara alternatif menghendaki hakim untuk memilih salah satu jenis pidana.
Namun dari beberapa sampel putusan yang peneliti temukan, tidak ada terpidana yang dijatuhi pidana denda. Di sisi lain, delik yang terbukti adalah delik yang memuat pidana denda.

Dilihat dari lamanya pidana penjara yang dijatuhkan dalam putusan-putusan yang peneliti kaji, terdapat lima putusan yang dapat digolongkan dalam katagori pidana penjara pendek (penjara pendek adalah pidana penjara yang dijatuhkan hakim yang lamanya di bawah 6 bulan). Penggunaan pidana penjara pendek dalam putusan pemidanaan mendapatkan banyak kritik, diantaranya dapat dituliskan sebagai berikut: ${ }^{40}$

1. Kongres II PBB tentang The Prevention of Crime and Treatment on Offender tahun 1960 yang memberikan pengakuan kaitannya dengan penggunaan penjara pendek yang berbahaya. Karena ada kemungkinan pelanggar akan terkontaminasi dan sedikit atau malah tidak sama sekali mendapatkan pelatihan yang konstruktif. Oleh karena itu, penggunaan penjara pendek secara luas tidak dikehendaki. Namun di sisi lain, kongres juga mengakui perlunya penjara pendek dalam hal-hal tertentu dengan memperhatikan tujuan keadilan.

2. Wolf Middendorf yang menyatakan pidana penjara pendek tidak memiliki reputasi yang baik.

3.Johannes Andenaes menyatakan bahwa penjara pendek merupakan suatu pemecahan yang buruk, karena tidak memberikan kesempatan yang melakukan untuk melakukan pekerjaan rehabilitasi.

4.S.R. Brody menyatakan lamanya waktu yang dijalani seseorang dalam penjara tidak memberikann pengaruh pada proses penghukuman kembali (reconviction).

Dengan demikian, berdasarkan beberapa kritik atas penggunaan penjara

40 Barda Nawawi Arief, Kapita Selekta Hukum Pidana, Bandung: Citra Aditya Bhakti, 2003, hal 34-42. 
pendek, seharusnya juga dipertimbangkan oleh hakim dalam menjatuhkan putusan pemidanaan. Hakim harus mempertimbangkan segala aspek keburukan dari penggunaan penjara pendek. Namun demikian, peneliti juga menyetujui pandangan dari Kongres PBB yang menyatakan, dalam kasus-kasus tertentu, dengan mempertimbangkan rasa keadilan, penjatuhan penjara pendek tetap diperlukan.

Melihat dari sisi negatif penggunaan penjara pendek bagi terpidana, idealnya sudah mulai dikemukakan modelmodel alternatif pemidanaan sebagai pengganti pidana penjara pendek. Salah satu yang bisa dilakukan dalam kondisi saat ini adalah penjatuhan pidana denda sebagai pengganti pidana penjara pendek. Sayangnya, untuk saat ini, solusi belum bisa terlaksana dengan optimal. Hal ini dapat kita lihat dari beberapa putusan yang peneliti kaji, dimana tidak ada satupun terpidana yang dijatuhkan pidana denda, kecuali terhadap putusan nomor 18/Pid.B/ 2009 /PN.Bjn.

Tindak pidana yang terbukti dalam putusan nomor 18/Pid.B/ 2009 /PN.Bjn adalah tindak pidana ekonomi sebagaimana diatur dalam Pasal 6 ayat (1) huruf a UU Drt. No. 7 Tahun 1955. Ketentuan pasal aquo, menempatkan pidana denda dikumulasikan dengan pidana penjara. Model perumusan kumulasi menghendaki hakim menjatuhkan segala jenis pidana yang diancamkan. Model perumusan sanksi kumulatif pada dasarnya adalah model yang kaku. Dikarenakan model sanksi dalam pasal aquo dirumuskan secara kumulatif, maka hakim tidak punya pilihan lain untuk menjatuhkan pidana penjara dan denda sekaligus.

Sebagai suatu bentuk respon atas jarangnya pidana denda dijatuhkan, Mahkamah Agung mengeluarkan Peraturan MA No 2 Tahun 2012 tentang Penyesuaian Batas Tindak Pidana Ringan dan Jumlah Denda dalam KUHP. Dari konsideran perma, dapat kita simpulkan bahwa rasio utama dari munculnya perma adalah sebagai suatu bentuk respon/kritik terhadap nominal/besaran denda dalam KUHP. MA menyatakan bahwa nilai uang yang ada dalam KUHP sudah tidak sesuai dengan kondisi saat ini.

Berdasarkan konsideran Perma, dapat disimpulkan bahwa nominal pidana denda dalam KUHP menjadi permasalahan utama bagi hakim dalam menjatuhkan pidana denda. Namun menurut peneliti, permasalahan tidak hanya terletak pada alasan tersebut saja. Peneliti menilai bahwa alasan jarangnya penjatuhan pidana denda oleh hakim diakibatkan juga karena paradigma pemidanaan masih berorientasi pada pembalasan. Dengan demikian, penjara masih menjadi primadona. Dalam tujuan pemidanaan yang bersifat retributif, pidana dijatuhkan semata-mata karena seseorang telah melakukan suatu kejahatan atau tindak pidana. Pidana merupakan akibat mutlak yang harus ada sebagai suatu pembalasan kepada orang yang telah berbuat jahat. ${ }^{41}$

Munculnya Perma No. 2 Tahun 2012 harus mendapat apresiasi. Peneliti memandang bahwa Perma tersebut pada hakikatnya merupakan suatu kritik konstruktif terhadap KUHP. Hal ini dapat dengan jelas kita lihat dalam konsideran nomor 3 yang menyatakan:

Bahwa materi perubahan KUHP pada dasarnya merupakan materi undangundang, namun mengingat perubahan KUHP diperkirakan akan memakan waktu yang cukup lama sementara perkara-perkara terus masuk ke pengadilan, Mahkamah Agung memandang perlu melakukan penyesuaian nilai rupiah yang ada dalam KUHP berdasarkan harga emas yang berlaku pada tahun 1960 .

${ }^{41}$ Herbert L. Packer, The Limits of the Criminal Sanction, (California: Stanford University Press, 1968), hal 9. 
Ketentuan Pasal 3 Perma No. 2 Tahun 2012 menyatakan tiap jumlah maksimum hukuman denda yang diancamkan dalam KUHP, kecuali Pasal 303 ayat (1) dan ayat (2), 303 bis ayat (1) dan ayat (2), dilipatgandakan menjadi 10.000 (sepuluh ribu kali). Dengan adanya ketentuan tersebut, maka setiap ancaman pidana denda dalam KUHP dilipatgandakan sebesar 10.000 kali. Ketentuan ini dimaksudkan sebagai suatu bentuk penyesuaian nominal pidana denda dalam KUHP agar dapat menyesuaikan dengan kondisi perekonomian saat ini.
Walaupun MA sudah mengeluarkan Perma No. 2 Tahun 2012, dengan harapan agar hakim lebih mempertimbangkan penjatuhan denda terhadap terpidana dalam kasus-kasus tertentu, namun ternyata dalam prakteknya, peneliti menemukan bahwa perma tersebut tidak efektif. Dalam hal ini, penulis mencoba untuk mengkaji efektifitas penjatuhan pidana denda pasca keluarnya Perma No 2 Tahun 2012 menggunakan pendekatan kasus. Dalam pembahasan sebelumnya, lebih dititikberatkan terhadap efektifitas penjatuhan pidana denda sebelum keluarnya Perma No. 2 Tahun 2012.

Dalam kajian kali ini, akan difokuskan pada efektifitas penjatuhan pidana denda pasca keluarnya Perma No. 2 Tahun 2012.

\begin{tabular}{|c|c|c|c|c|c|}
\hline No & $\begin{array}{l}\text { Nomor } \\
\text { Putusan }\end{array}$ & Terdakwa & $\begin{array}{l}\text { Tindak Pidana } \\
\text { yang terbukti }\end{array}$ & $\begin{array}{c}\text { Ancaman Pidana } \\
\text { Pasal ybs }^{42}\end{array}$ & Putusan \\
\hline 1. & $\begin{array}{l}\text { 96/Pid.B/2012 } \\
\text { /PN.Dmk }\end{array}$ & $\begin{array}{l}\text { Paul Maridas bin } \\
\text { Suripto }\end{array}$ & $\begin{array}{l}\text { Penganiayaan ringan } \\
\text { (Pasal } 352 \text { ayat (1) } \\
\text { KUHP) }\end{array}$ & $\begin{array}{l}\text { penjara paling lama } \\
\text { tiga bulan atau pidana } \\
\text { denda paling banyak } \\
\text { empat ribu lima ratus } \\
\text { rupiah }\end{array}$ & 2 bulan penjara \\
\hline 2. & $\begin{array}{c}03 \\
\text { /Daf.Pid.C/20 } \\
\text { 13/ PN.Slk }\end{array}$ & Herman alias Man & $\begin{array}{l}\text { Pencurian ringan } \\
\text { (Pasal } 364 \text { KUHP) }\end{array}$ & $\begin{array}{l}\text { pidana penjara paling } \\
\text { lama tiga bulan atau } \\
\text { pidana denda paling } \\
\text { banyak dua ratus lima } \\
\text { puluh rupiah }\end{array}$ & 10 hari penjara \\
\hline 3. & $\begin{array}{c}\text { 2/ } \\
\text { DAF.PID.C/ } \\
\text { 2014/ PN Ttn. }\end{array}$ & $\begin{array}{l}\text { Sawani binti Nyak } \\
\text { Diwan }\end{array}$ & $\begin{array}{ll}\text { Penghinaan } & \text { ringan } \\
(315 \mathrm{KUHP}) & \end{array}$ & $\begin{array}{l}\text { pidana penjara paling } \\
\text { lama empat bulan dua } \\
\text { minggu atau pidana } \\
\text { denda paling banyak } \\
\text { empat ribu lima ratus } \\
\text { rupiah }\end{array}$ & 1 bulan penjara \\
\hline 4. & $\begin{array}{c}\text { 7/PID.C/2014/ } \\
\text { PN. KBJ }\end{array}$ & Tuhu Raja Munthe & $\begin{array}{l}\text { Pengrusakan ringan } \\
\text { (407 ayat (1) KUHP) }\end{array}$ & $\begin{array}{l}\text { pidana penjara paling } \\
\text { lama tiga bulan atau } \\
\text { pidana denda paling } \\
\text { banyak dua ratus lima } \\
\text { puluh rupiah }\end{array}$ & 1 bulan penjara \\
\hline 5. & $\begin{array}{c}\text { 175/Pid.C/201 } \\
\text { 4/PN Rap }\end{array}$ & $\begin{array}{lr}\text { Muslim } & \text { Harahap } \\
\text { dan } & \text { Mursid } \\
\text { Harahap } & \end{array}$ & $\begin{array}{l}\text { Pengrusakan ringan } \\
\text { (407 ayat (1) KUHP) }\end{array}$ & $\begin{array}{l}\text { pidana penjara paling } \\
\text { lama tiga bulan atau } \\
\text { pidana denda paling } \\
\text { banyak dua ratus lima } \\
\text { puluh rupiah }\end{array}$ & $\begin{array}{l}\text { Masing-masing } \\
\text { dengan pidana } 14 \\
\text { hari penjara }\end{array}$ \\
\hline 6. & $\begin{array}{c}\text { 246/ Pid.B / } \\
2015 \text { / PN Btl. }\end{array}$ & $\begin{array}{l}\text { 1. Iswoko bis } \\
\text { Sastro Wiyarjo; } \\
\text { 2. Sukamto binn }\end{array}$ & $\begin{array}{l}\text { Perjudian (Pasal } 303 \\
\text { bis ayat (1) KUHP) }\end{array}$ & $\begin{array}{l}\text { Penjara maks } 4 \text { tahun } \\
\text { atau denda maks Rp. } \\
10.000 .000,00\end{array}$ & $\begin{array}{l}\text { Masing-masing } \\
\text { terdakwa dijatuhkan } \\
\text { pidana penjara } 3\end{array}$ \\
\hline
\end{tabular}

${ }^{42}$ Berdasarkan Perppu No. 18 Tahun 1960, semua denda dilipatgandakan menjadi 15 kali. 


\begin{tabular}{|c|c|c|c|c|c|}
\hline & & $\begin{array}{l}\text { Amat Nangsri; } \\
\text { 3. Pujo Wiyadi } \\
\text { alias Ngatijo } \\
\text { bin Amar Sukir; } \\
\text { 4. Mugiyantoro } \\
\text { alias Sotong bin } \\
\text { Madyo Pawiro; } \\
\text { 5. Waluyo } \\
\text { Kusmadi bin } \\
\text { Hardi Suminto; } \\
\text { 6. Sumardiono } \\
\text { alias Gandung } \\
\text { bin Sastro } \\
\text { Wardi. }\end{array}$ & & & bulan 15 hari \\
\hline 7. & $\begin{array}{c}\text { No.42/Pid.C/2 } \\
\text { 015/PN-Sim }\end{array}$ & $\begin{array}{ll}\text { Lisbon } & \text { Jawanter } \\
\text { Hutasoit } & \end{array}$ & $\begin{array}{l}\text { Pencurian ringan } \\
\text { (Pasal } 364 \text { KUHP) }\end{array}$ & $\begin{array}{l}\text { pidana penjara paling } \\
\text { lama tiga bulan atau } \\
\text { pidana denda paling } \\
\text { banyak dua ratus lima } \\
\text { puluh rupiah }\end{array}$ & 2 bulan penjara \\
\hline
\end{tabular}

Berdasarkan dari sampel putusan pengadilan negeri yang diambil dari berbagai daerah, pasca keluarnya Perma No. 2 Tahun 2012 dapat dilihat bahwa dari tujuh putusan yang peneliti jadikan sampel, tidak ada satupun putusan yang menjatuhkan pidana denda. Dalam beberapa putusan, terlihat majelis hakim sudah mempertimbangkan Perma No. 2 dalam putusannya. Hal ini dapat dilihat dalam Putusan No. 42/Pid.C/2015/PN-Sim. Dalam putusan tersebut, majelis hakim menjadikan Perma No. 2 sebagai dasar pertimbangan dalam menjatuhkan pemidanaan. Namun sayangnya hakim lebih memilih menjatuhkan pidana penjara pendek, selama 2 bulan. Di sisi lain, tindak pidana yang terbukti dilakukan pelaku dalam perkara tersebut adalah tindak pidana pencurian ringan (Pasal 364 KUHP), dimana ancaman pidananya adalah pidana penjara paling lama tiga bulan atau pidana denda paling banyak dua ratus lima puluh rupiah. Model perumusan sanksi adalah alternatif, sehingga hakim seharusnya bisa mempertimbangkan penjatuhan pidana denda dibandingkan dengan penjara. Mengingat juga keburutkan dari pidana penjara pendek.
Beberapa putusan di atas menunjukkan bahwa pidana penjara masih menjadi primadona, bahkan setelah keluarnya Perma. Dengan demikian, dapat disimpulkan bahwa Perma No. 2 Tahun 2002 tidak serta merta memberikan efektivitas dalam penjatuhan pidana denda terhadap pelaku tindak pidana yang melanggar ketentuan dalam KUHP. Nampaknya hal ini masih menjadi pekerjaan rumah bagi pemerintah untuk dapat memberikan solusi yang jitu agar pidana denda dapat dipertimbangkan sebagai alternatif dari pidana penjara pendek.

\section{KESIMPULAN DAN SARAN Kesimpulan}

a. Dalam KUHP, pidana denda dijatuhkan terhadap kejahatan dan pelanggaran. Khusus untuk kejahatan, tidak semua kejahatan yang diatur dalam Buku II KUHP diancam dengan pidana denda. Untuk tindak pidana berupa kejahatan, pidana denda diancamkan terhadap 119 pasal di Buku II KUHP. Dengan demikian, sebanyak $32 \%$ kejahatan dalam Buku II KUHP memiliki ancaman sanksi pidana denda. Sanksi pidana denda dalam Buku II KUHP dirumuskan secara alternatif. Sedangkan untuk pelanggaran, pada 
umumnya pidana denda dijadikan sebagai ancaman baik dirumuskan secara tunggal (contoh Pasal 495 KUHP), alternatif (contoh Pasal 493 KUHP). Dalam Buku III, ada 4 pasal yang tidak mencantumkan sanksi pidana, yaitu Pasal 504, 505, 506, dan 520 KUHP. Ini berarti, sebesar $97 \%$ tindak pidana pelanggaran diancam dengan sanksi pidana denda.

b. Sebelum keluarnya Perma No. 2 Tahun 2012 tentang tentang Penyesuaian Batasan Tindak Pidana Ringan dan Jumlah Denda dalam KUHP, berdasarkan hasil penelitian dari berbagai putusan yang dijadikan sampel, peneliti tidak menemukan penjatuhan pidana denda terhadap kejahatan ringan maupun tindak pidana lain, yang memuat ancaman pidana denda. Dengan demikian, sebelum munculnya Perma No. 2 Tahun 2012 tentang Penyesuaian Batasan Tindak Pidana Ringan dan Jumlah Denda dalam KUHP, pidana penjara masih menjadi jenis pidana primadona yang dijatuhkan oleh hakim. Pasca keluarnya Perma No. 2 Tahun 2012 tentang Penyesuaian Batasan Tindak Pidana Ringan dan Jumlah Denda dalam KUHP, tidak tampak terjadi perubahan. Walaupun dalam beberapa sampel putusan yang peneliti kaji, Perma No. 2 Tahun 2012 tentang Penyesuaian Batasan Tindak Pidana Ringan dan Jumlah Denda dalam KUHP sudah dijadikan sebagai bagian dari pertimbangan hakim, namun dari hasil penelitian, peneliti tidak menemukan putusan yang menjatuhkan pidana denda.

\section{Saran}

a. Perubahan paradigma dari aparat penegak hukum, khususnya hakim terkait dengan pidana denda. Hal ini perlu dilakukan mengingat keburukan-keburukan yang ditimbulkan akibat dari pidana penjara pendek.

b. Kedudukan Perma hanya mengikat terhadap kalangan internal Mahkamah Agung, dalam hal ini hanya hakim. Secara prinsipal, Perma tidak mengikat polisi maupun jaksa. Oleh karena itu, Nota Kesepakatan Bersama yang dilakukan pihak Mahkamah Agung, Kementrian Hukum dan HAM, Kepolisian RI, dan Kejaksaan RI harus tersosialisasi dengan baik sampai kepada "akar rumput".

\section{DAFTAR PUSTAKA}

\section{A. Buku}

Anwar, Yesmil dan Adang. Pembaruan Hukum Pidana Reformasi Hukum Pidana. Jakarta: Gramedia Widiasarana Indonesia. 2008.

Asworth, Andrew dan Martin Wasik (ed). Fundamentals of Sentencing TheoryEssays in Honour of Andrew von Hirsch. Oxford: Clarendon Press. 1998.

Bemmelen, J. M. Van. Hukum Pidana 1 Hukum Pidana Material Bagian Umum, terjemahan Hasnan. Bandung: Binacipta, 1987.

Hamzah, Andi. Sistem Pidana dan Pemidanaan Indonesia. Jakarta: Pradnya Paramita. 1993. Asas Hukum Pidana. Jakarta: Rineka Cipta. 1994.

Hiariej, Eddy O.S. Prinsip-Prinsip Hukum Pidana. Yogjakarta: Cahaya Atma Pustaka, 2014.

Hoefnagels, G. Peter. The Other Side of Criminology-An Inversion of the Concept of Crime. Holland: KluwerDeventer. 1969.

Huda, Chairul. Dari Tiada Pidana Tanpa Kesalahan Menuju Kepada Tiada Pertanggungjawaban Pidana Tanpa Kesalahan: Tinjauan Kritis terhadap Teori Pemisahan Tindak Pidana dan Pertanggungjawaban Pidana. Jakarta: Kencana Prenada Media Group. 2006.

Muladi dan Barda Nawawi Arief, TeoriTeori dan Kebijakan Pidana. Bandung: Alumni. 2005.

Nawawi Arief, Barda. Kapita Selekta Hukum Pidana. Bandung: Citra Aditya Bhakti. 2003. Masalah Penegakan Hukum dan Kebijakan Hukum Pidana Dalam 
Penanggulangan Kejahatan. Jakarta: Kencana. 2008.

Kebijakan Legislatif dalam Penanggulangan Kejahatan dengan Pidana Penjara. Yogjakarta: Genta Publishing. 2010.

\section{— Bunga Rampai Kebijakan Hukum Pidana Perkembangan Penyusunan Konsep KUHP Baru. Jakarta: Kencana Prenada Media Group. 2011.}

Packer, Herbert L. The Limits of the Criminal Sanction. California: Stanford University Press. 1968.

Remmelink, Jan. Hukum Pidana Komentar Atas Pasal-Pasal Terpenting dari Kitab Undang-Undang Hukum Pidana Belanda dan Padanannya dalam Kitab Undang-Undang Hukum Pidana Indonesia. Jakarta: Gramedia Pustaka Utama. 2003.

Sakidjo, Aruan dan Bambang Poernomo. Hukum Pidana Dasar Aturan Umum Hukum Pidana Terkodifikasi. Jakarta: Ghalia Indonesia. 1990.

Soekanto, Soerjono. Pengantar Penelitian Hukum. Jakarta: UI Perss. 2006.

Soemitro, Ronny Hanitijo. Metodologi Penelitian Hukum dan Jurimetri, (Jakarta: Ghalia Indonesia. 1994.

Sudarto. Hukum Pidana dan Perkembangan Masyarakat - Kajian Terhadap Pembaruan Hukum Pidana. Bandung: Sinar Baru. 1983. Hukum Pidana. Semarang: Yayasan Sudarto. 1990.

Zainal Farid, Andi dan Andi Hamzah. Bentuk-Bentuk Khusus Perwujudan Delik (Percobaan, Penyertaan, dan Gabungan Delik) dan Hukum Penitensier. Jakarta: Rajagrafindo. 2006.

\section{B. Makalah/Artikel Ilmiah/Pidato}

\section{Pengukuhan}

Elsam. Pemidanaan, Pidana, dan Tindakan dalam Rancangan KUHP. Position Papper Advokasi oleh ELSAMLembaga Studi dan Advokasi Masyarakat. 2005.

Nawawi Arief, Barda. Penelitian Hukum Normatif (Suatu Upaya Reorientasi Pemahaman), dipaparkan dalam Penataran Metodologi Penelitian Hukum, Universitas Jendral
Soedirman, Purwokerto, September 1995, hal 5-6. 